\title{
PENGARUH KEPUASAN KERJA DAN KOMITMEN ORGANISASI TERHADAP KINERJA PEGAWAI PADA KANTOR KECAMATAN PARIGI KOTA
}

\author{
MEGA DELFIANA TOLIS \\ BAKRI HASANUDDIN \\ WIRI WIRASTUTI \\ Program Studi S1 Manajemen, Fakultas Ekonomi, Universitas Tadulako \\ Email: mega.defianat11@gmail.com
}

\begin{abstract}
This study aims to determine whether Job Satisfaction and Organizational Commitment simultaneously or partially affect the Performance of employees at the Office District Parigi City. This study uses quantitative research which aims to explain the relationship between two or more variables with the sample of all employees at the Parigi City District Office amounting to 39 people and data analysis techniques used is multiple linear regression analysis. The results of hypothesis analysis and testing can be concluded bawha: (1) berdasarka regression test results obtained Sig. F of $0.000<\alpha$ 0.05 which can be interpreted that the variable Job Satisfaction and Organizational Commitment simultaneously significant to the performance of employees. (2) based on the regression test results obtained variable Job satisfaction has a significance level t sig. 0,003 $<\alpha 0,05$ can be interpreted that job satisfaction variable partially have an effect on signifikan to employee performance. (3) based on regression test results obtained variable Organizational commitment has significance level t sig. 0,033 $<\alpha 0,05$ can be interpreted that variable of Commitment of organization partially have an effect on signifikan to employee performance.
\end{abstract}

Keywords: Job Satisfaction, Organizational Commitment, Performance

\section{Abstrak}

Penelitian ini bertujuan untuk mengetahui apakah Kepuasan Kerja dan Komitmen Organisasi secara simultan maupun parsial berpengaruh terhadap Kinerja pegawai pada Kantor Kecamatan Parigi Kota. Penelitian ini menggunakan penelitian Kuantitatif yang bertujuan untuk menjelaskan hubungan antara dua variabel atau lebih dengan sampel semua pegawai pada Kantor Kecamatan Parigi Kota yang berjumlah 39 orang dan teknik analisis data yang digunakan adalah analisis regresi linier berganda. Hasil analisis dan pengujian hipotesis dapat disimpulkan bahwa: (1) berdasarkan hasil uji regresi diperoleh Sig. F sebesar $0,000<\alpha 0,05$ yang dapat diartikan bahwa variabel Kepuasan kerja dan Komitmen organisasi secara simultan berpengaruh signifikan terhadap Kinerja pegawai. (2) berdasarkan hasil uji regresi diperoleh variabel Kepuasan kerja memiliki tingkat signifikansi $\mathrm{t}$ sig. $0,003<\alpha 0,05$ dapat diartikan bahwa variabel Kepuasan kerja secara parsial berpengaruh signifikan terhadap Kinerja pegawai. (3) berdasarkan hasil uji regresi diperoleh variabel Komitmen organisasi memiliki tingkat signifikansi t sig. $0,033<\alpha 0,05$ dapat diartikan bahwa variabel Komitmen organisasi secara parsial berpengaruh signifikan terhadap Kinerja pegawai.

Kata kunci: Kepuasan Kerja, Komitmen Organisasi, Kinerja

\section{PENDAHULUAN}

Banyak faktor yang menyebabkan sumber daya manusia memiliki kinerja yang unggul, sehingga mampu mendorong keberhasilan organisasi, antara lain kepuasan kerja dan komitmen yang memiliki pengaruh terhadap kinerja individu, Sudarmanto (2014:29). Robbins (2001:149) menyatakan bahwa faktor-faktor yang lebih penting yang mendorong kepuasan kerja ialah kerja yang secara menantang, ganjaran yang pantas, kondisi kerja yang mendukung, rekan kerja yang mendukung dan kesesuaian antar kepribadian dan pekerjaan. Pegawai yang merasa puas terhadap pekerjaannya dan menganggap pekerjaanya sebagai suatu yang menyenangkan akan cenderung memiliki kinerja yang baik dan karyawan yang puas akan mampu meningkatkan kepuasan pelanggan. Adanya peningkatan kerja pada karyawan tentu berdampak pada kinerja yang ditunjukannya, Robbins (2006:103). Selain kepuasan 
Tolis, M.D.

kerja, variabel yang berpengaruh terhadap kinerja pegawai adalah komitmen organisasi. Komitmen adalah suatu keterkaitan karyawan terhadap organisasinya baik secara efektif, kontinuan, dan normatif yang mendorongnya bersedia mengorbankan seluruh waktunya untuk organisasi tersebut. komitmen dari seorang pegawai terhadap organsisasinya dapat menjadi instrumen penting untuk meningkatkan kinerja dari pegawai. Alen dan Meyer dalam Sudarmanto (2009:102).

Menurut Nawawi (2006:66) dalam melaksanakan pekerjaan dilingkungan sebuah organisasi atau perusahaan mencakup lima unsur yaitu kuantitas kerja, kualitas kerja, jangka waktu, kehadiran dan kemampuan bekerja sama. Kinerja lebih dari pada prestasi kerja, kinerja tidak lain adalah tampilan kerja yang merupakan hasil implementasi dan praktik latihan kerja sejak awal masuk kerja hingga saat ini. Performance atau kinerja adalah hasil kerja yang dapat dicapai oleh seseorang atau sekelompok orang yang dalam suatu organisasi, sesuai dengan wewenang dan tanggung jawab masing-masing. Instansi pemerintah seperti Kantor Kecamatan Parigi merupakan suatu organisasi yang mempunyai beragam tujuan. Pemanfaatan sumber daya manusia yang efektif dan terarah menjadi kunci peningkatan kinerja pegawai bagi organisasi yang menjalankan aktivitas kegiatannya, baik pemerintah daerah maupun pusat.

Menurut pengamatan penulis sesuai dengan observasi yang dilakukan, bahwa yang terjadi pada kantor kecamatan parigi kota adalah dimana kinerja pegawai yang belum bisa dikatakan baik dikarenakan oleh rendahnya tingkat kepuasan kerja yang dirasakan dan pegawai yang tidak memiliki komitmen yang kuat dinyatakan oleh dua pegawai yang di jadikan narasumber oleh peneliti yaitu pegawai PNS dan non PNS, dilihat dari kondisi pekerjaan itu sendiri yang mana pekerjaan dalam kantor kecamatan ini kurang menantang dan fasilitas yang belum cukup menunjang aktifitas kantor mengakibatkan pegawai merasakan bosan dan muncul rasa malas untuk masuk kantor. Gaji yang diterima oleh pegawai honorer belum sesuai dengan UMR, lingkungan kerja kurang kondusif yang menjadikan pegawai kurang nyaman dalam bekerja, dan rekan kerja yang memiliki perbedaan karakteristik, kurangnya komunikasi antar sesama rekan kerja, serta tingkat loyal pegawai terhadap organisasi ini sangat kurang dan pegawai merasa tidak memiliki komitmen yang kuat terhadap kantor ini, dinyatakan oleh beberapa pegawai yang malas masuk kantor, datang dan pulang tidak sesuai jam yang ditentukan kantor, dan ingin pindah atau mencari tempat kerja yang lain namun terkendala dengan keadaan dimana langkahnya lapangan kerja ketika mereka akan keluar dari pekerjaannya.

\section{KAJIAN LITERATUR DAN PENGEMBANGAN HIPOTESIS}

\section{Kepuasaan kerja}

Kepuasaan merupakan keinginan dan harapan yang sudah tercapai pada diri seseorang. Hakikatnya adalah sebuah rasa puas untuk maju, dan mendapatkan penghargaan maupun hal yang berhubungan dengan masalah pengawasan dan hubungan karyawan, Rivai dan Mulyadi (2012:246). Menurut Noe dkk (2006: 436) mendefinisikan kepuasan kerja sebagai perasaan senang yang dihasilkan dari persepsi bahwa pekerjaannya memenuhi atau memungkinkan pemenuhan nilai-nilai penting pekerjaannya.

\section{Faktor-faktor yang mempengaruhi kepuasan kerja}

Robbins (2001:149) menyatakan bahwa faktor-faktor yang lebih penting yang mendorong kepuasan kerja adalah

a. Kerja yang secara mental menantang

b. Ganjaran yang pantas

c. Kondisi kerja yang mendukung

d. Rekan kerja yang mendukung

e. Kesesuaian antara kepribadian pekerjaan 


\section{Komitmen organisasi}

Komitmen organisasional sebagai sebuah keadaan psikologi yang mengkarakteristikan hubungan karyawan dengan organisasi atau implikasinya yang mempengaruhi apakah karyawan akan tetap bertahan dalam organisasi atau tidak, yang teridentifikasi dalam tiga komponen yaitu komitmen afektif, komitmen kontinuan, dan komitmen normatif. Zurnali. C (2010:127). Komitmen organisasi atau loyalitas pekerja adalah tingkatan dimana pekerja mengidentifikasi dengan organisasi dan ingin melanjutkan secara aktif berpartisipasi didalamnya. Newstrom (2011) dalam Wibowo (2016:430). Komitmen karyawan adalah kekuatan yang relatif dari individu dalam mengidentifikasikan keterlibatan dirinya kedalam bagian organisasi.

Menurut Alen dan Meyer dalam Sudarmanto (2009:102) Komitmen adalah suatu keterkaitan karyawan terhadap organisasinya baik secara efektif, kontinuan, dan normatif yang mendorongnya bersedia mengorbankan seluruh waktunya untuk organisasi tersebut. Komitmen terbagi atas tiga komponen, yaitu:

1. Komitmen afektif

2. Komitmen normatif

3. Komitmen kontinuan

\section{Kinerja}

Kinerja pegawai didefinisikan sebagai kemampuan pegawai dalam melakukan sesuatu keahlian tertentu. Kinerja pegawai sangatlah perlu, sebab dengan kinerja ini akan diketahui seberapa jauh kemampuan pegawai dalam melaksanakan tugas yang dibebankaan kepadanya. Untuk itu diperlukan penentuan kriteria yang jelas dan terukur serta ditetapkan secara bersama-sama yang dijadikan sebagai acuan. Lijan Poltak Sinambela dkk (2011: 136).

Menurut Prawirosentono (1999:2) Kinerja adalah hasil kerja yang dapat dicapai oleh seseorang atau sekelompok orang dalam suatu organisasi, sesuai dengan wewenang dan tanggung jawab masingmasing, dalam rangka upaya mencapai tujuan organisasi bersangkutan secara legal, tidak melanggar hukum dan sesuai dengan moral dan etika. Menurut Nawawi (2006:66) dalam melaksanakan pekerjaan dilingkungan sebuah organisasi atau perusahaan mencakup lima unsur sebagai berikut: Kuantitas hasil kerja yang dicapai

1. Kualitas hasil kerja yang dicapai

2. Jangka waktu

3. Kehadiran dan kegiatan selama hadir ditempat kerja

4. Kemampuan bekerjasama

\section{Hubungan Kepuasan Kerja dan Kinerja}

Setiap orang yang bekerja mengharapkan memperoleh kepuasaan dari tempatnya bekerja. Kepuasan akan mempengaruhi produktivitas yang sangat diharapkan manajer. Manajer perlu memahami apa yang harus dilakukan untuk menciptakan kepuasan kerja untuk meningkatkan kinerja karyawannya. Wibowo (2016:415). Kepuasan kerja memiliki hubungan yang cukup besar terhadap kinerja pegawai. Ini dapat dilihat bahwa kinerja seseorang akan meningkat ketika kepuasan kerja dari individu terpenuhi atau berada pada posisi yang tinggi.

\section{Hubungan Komitmen Organisasi dan Kinerja}

Komitmen organisasi terkait dengan kekuatan identifikasi individu dan keterlibatannya dalam organisasi tertentu, Sudarmanto (2014:102). Demikian, karyawan yang berkomitmen tinggi akan akan memiliki kinerja yang tinggi dan loyalitas untuk perusahaan. Sebaliknya, karyawan yang cenderung memiliki komitmen rendah, kinerjanya pun rendah dan loyalitas yang kurang terhadap perusahaan. 


\section{Kerangka Pemikiran}

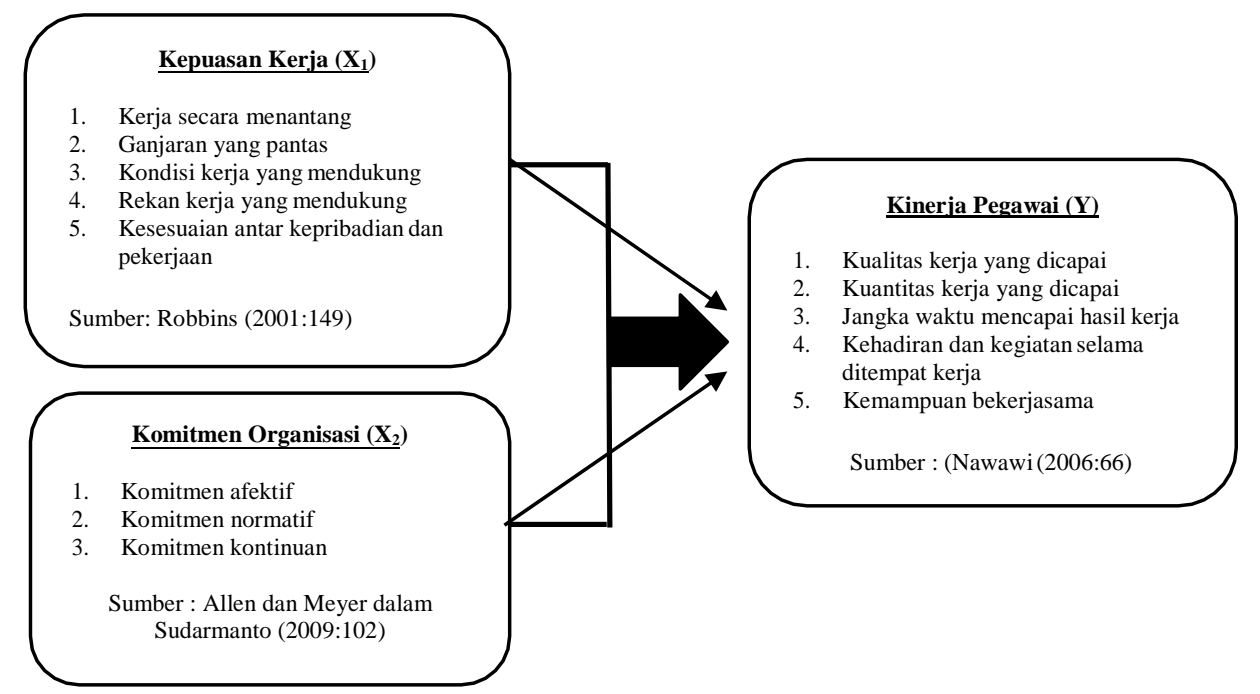

\section{Gambar.1 Kerangka Pikir}

\section{Hipotesis}

Berdasarkan permasalahan dan kerangka pemikiran diatas maka diajukan hipotesis penelitian sebagai berikut:

1. Kepuasan kerja dan Komitmen organisasi berpengaruh secara simultan terhadap Kinerja pegawai Kantor Kecamatan Parigi kota.

2. Kepuasan kerja berpengaruh secara parsial terhadap Kinerja pegawai Kantor Kecamatan Parigi kota.

3. Komitmen organisasi berpengaruh secara parsial terhadap Kinerja pegawai Kantor Kecamatan Parigi Kota.

\section{METODE PENELITIAN}

\section{Jenis Penelitian}

Jenis penelitian yang digunakan dalam penelitian ini menggunakan dasar penelitian kuantitatif (asosiatif), dengan alasan peneliti ingin menguji interpendensi pengaruh dua variabel, dalam hal ini Kepuasan kerja $\left(\mathrm{X}_{1}\right)$ dan Komitmen organisasi $\left(\mathrm{X}_{2}\right)$ Kantor Kecamatan yang digunakan, serta bagaimana pengaruhnya terhadap Kinerja pegawai (Y). Penelitian asosiatif merupakan penelitian yang menanyakan hubungan antar dua variabel atau lebih. Sugiyono (2014: 92).

\section{Lokasi Penelitian dan Jenis Sumber Data}

Penelitian ini dilakukan di Kantor Camat Parigi Kota Kabupaten Parigi Moutong dengan objek penelitian tentang kepuasan kerja dan komitmen organisasi terhadap kinerja pegawai pada Kantor Kecamatan Parigi kota. Jenis data yang digunakan dalam penelitian ini adalah data kualitatif dan data kuantitatif, Sumber data yang digunakan dalam penelitian ini adalah data primer dan data sekunder.

\section{Populasi dan Sampel}

Populasi dalam penelitian ini adalah seluruh pegawai Kantor Kacamatan Parigi Kota yang berjumlah 39 orang. PNS berjumlah 24 orang dan honorer berjumlah 15 orang, dimana semua unsur populasi akan dijadikan sampel. Metode yang digunakan yaitu metode sensus. Metode sensus adalah metode pengambilan sampel yang dilakukan terhadap seluruh populasi dari obyek yang ditentukan. Sampel dalam penelitian ini adalah keseluruhan dari populasi yang ada atau disebut dengan metode sensus (full sampling). 


\section{Teknik pengumpulan data}

1. Observasi, merupakan teknik pengumpulan data dimana peneliti mengadakan pengamatan terhadap suatu objek yang akan diteliti. Pengamatan yang dimaksud dilakukan dengan cara terjun langsung ke lokasi yang menjadi objek penelitian

2. Wawancara, pada penelitian ini dilakukan dengan mengajukan pertanyaan-pertanyaan kepada beberapa orang pegawai selaku responden secara acak.

3. Kuesioner (angket), adalah metode pengumpulan data yang dilakukan dengan cara memberi seperangkat pertanyaan atau pernyataan tetulis kepada responden untuk dijawab.

4. Dokumentasi, yang berkaitan dengan literatur buku, laporan, website, publikasi melalui dunia maya (internet), atau bukti lainnya yang berkaitan dengan penelitian ini.

\section{Teknik analisis data}

Menurut Sugiyono (2010:149) Analisis regresi berganda digunakan untuk meramalkan bagaimana keadaan (naik turunnya) variabel dependen, bila dua atau lebih variabel independen sebagai indikator. Analisis digunakan dengan melibatkan dua atau lebih variabel bebas antara variabel dependen $(\mathrm{Y})$ dan variabel independen $\left(\mathrm{X}_{1}\right.$ dan $\left.\mathrm{X}_{2}\right)$. Persamaan regresinya sebagai berikut:

$\mathrm{Y}=\mathrm{a}+\mathrm{b}_{1} \mathrm{X}_{1}+\mathrm{b}_{2} \mathrm{X}_{2}$

Dimana:

$\mathrm{Y} \quad$ = Kinerja pegawai (variabel dependen)

$\mathrm{a} \quad=$ Konstanta

$\mathrm{b}_{1}, \mathrm{~b}_{2}=$ Koefisien regresi parsial

$\mathrm{X}_{1}=$ Kepuasan kerja (variabel independen)

$\mathrm{X}_{2} \quad$ Komitmen organisasi (variabel independen)

Menurut Sugiyono (2011:192) uji F digunakan untuk mengetahui apakah secara simultan koefisien variabel bebas mempunyai pengaruh nyata atau tidak terhadap variabel terikat, untuk menguji apakah masing-masing variabel bebas berpengaruh secara signifikan terhadap variabel terikat secara bersamasama dengan $\alpha=0,05$. Maka cara yang dilakukan adalah:

a. Bila (P-value) $<0,05$ artinya variabel independen secara simultan mempengaruhi variabel dependen

b. Bila (P-value) $>0,05$ artinya variabel independen secara simultan tidak mempengaruhi variabel dependen.

Menurut Sugiyono (2011:194) uji t digunakan untuk mengetahui masing-masing sumbangan variabel bebas secara parsial terhadap variabel terikat, menggunakan uji masing-masing koefisien regresi variabel bebas apakah mempunyai pengaruh yang bermakna atau tidak terhadap variabel terikat. Untuk menguji apakah masing-masing variabel bebas berpengaruh secara signifikan terhadap variabel terikat secara parsial dengan $\alpha=0,05$. Maka cara yang dilakukan adalah

a. Bila (P-value $)<0,05$ artinya variabel independen secara parsial mempengaruhi variabel dependen.

b. Bila (P-value) $>0,05$ artinya variabel independen secara parsial tidak mempengaruhi variabel dependen. 
Tolis, M.D.

\section{HASIL DAN PEMBAHASAN}

Tabel.1 Hasil Perhitungan Regresi Linear Berganda

Coefficients $^{\mathrm{a}}$

\begin{tabular}{|c|c|c|c|c|c|}
\hline \multirow[b]{2}{*}{ Model } & \multicolumn{2}{|c|}{ Unstandardized Coefficients } & \multirow{2}{*}{$\begin{array}{c}\begin{array}{c}\text { Standardized } \\
\text { Coefficients }\end{array} \\
\text { Beta }\end{array}$} & \multirow[b]{2}{*}{$\mathrm{t}$} & \multirow[b]{2}{*}{ Sig. } \\
\hline & B & Std. Error & & & \\
\hline 1 (Constant) & 1,322 & ,374 & & 3,531 & 001 \\
\hline Kepuasan_kerja_X1 & ,395 & 126 & ,477 & 3,134 &, 003 \\
\hline Komitmen_organisasi_X2 & 244 &, 110 & ,338 & 2,216 & 033 \\
\hline Multiple R & & F- hitung & $=23,360$ & & \\
\hline $\mathrm{R}$ Square $\left(\mathrm{R}^{2}\right)$ & & Sig. F & $=0,000$ & & \\
\hline
\end{tabular}

Berdasarkan nilai dari tabel.1 di atas, maka persamaan regresi linear berganda dapat dirumuskan sebagai berikut:

$Y=1,322+0,395 X 1+0,244 X 2$

Berdasarkan persamaan tersebut maka dapat dinyatakan bahwa variabel independen $\left(\mathrm{X}_{1}\right.$ dan $\left.\mathrm{X}_{2}\right)$ memberi pengaruh positif terhadap variabel dependen (Y).

a. Nilai konstanta (a) adalah 1,322, artinya apabila variabel kepuasan kerja $\left(\mathrm{X}_{1}\right)$ dan komitmen organisasi $\left(\mathrm{X}_{2}\right)$ nilainya 0 , maka kinerja pegawai kantor kecamatan parigi kota tetap positif 1,322.

b. Nilai koefisien regresi variabel kepuasan kerja $\left(X_{1}\right)$ bernilai positif yaitu 0,395 . Hal ini menyatakan bahwa jika nilai kepuasan kerja meningkat maka akan meningkatkan pula kinerja pegawai kantor kecamatan parigi kota.

c. Nilai koefisien regresi variabel komitmen organisasi $\left(\mathrm{X}_{2}\right)$ bernilai positif yaitu 0,244 . Hal ini menyatakan bahwa jika nilai komitmen organisasi meningkat maka akan meningkat pula kinerja pegawai kantor kecamatan parigi kota.

\section{Pengujian Hipotesis (Uji F dan Uji t)}

Pengujian hipotesis digunakan untuk mengetahui pengaruh signifikan secara serempak maupun secara parsial dari variabel independen terhadap variabel dependen, maka digunaka uji F dan uji t. Uji $\mathrm{F}$ (Serempak) adalah suatu metode untuk melihat apakah variabel independen yang diteliti mempunyai pengaruh secara serempak terhadap variabel dependen. Uji t digunakan untuk mengetahui apakah variabel independen yakni kepuasan kerja dan komitmen organisasi yang diteliti memiliki pengaruh secara parsial terhadap variabel dependen yakni kinerja.

Berdasarkan hasil uji regresi pada tabel di atas, diperoleh Sig.F sebesar 0,000 < 0,05, yang dapat diartikan bahwa variabel kepuasan kerja dan komitmen organisasi secara serempak berpengaruh signifikan terhadap variabel kinerja pegawai. berdasarkan hasil tersebut dapat disimpulkan bahwa $\mathrm{H}_{0}$ ditolak dan $\mathrm{H}_{\mathrm{a}}$ diterima.

Uji t dilakukan dengan membandingkan nilai t signifikansi lebih kecil dari $\alpha 0,05$ maka dapat dipastikan bahwa variabel independen berpengaruh signifikan terhadap variabel dependen, sebaliknya jika nilai t signifikansi lebih besar dari $\alpha 0,05$ maka dapat dipastikan bahwa variabel independen berpengaruh tidak signifikan terhadap variabel dependen, dapat dijelaskan hasil uji t dari variabel independen adalah sebagai berikut:

a. Kepuasan Kerja $\left(\mathrm{X}_{1}\right)$

Variabel kepuasan kerja memiliki tingkat signifikansi $t$ sig. $(0,003)<\alpha(0,05)$. Hal ini menunjukkan bahwa hipotesis yang menyatakan "kepuasan kerja secara parsial berpengaruh signifikan terhadap kinerja pegawai pada Kantor Kecamatan Parigi Kota" terbukti atau bahwa $\mathrm{H}_{0}$ ditolak dan $\mathrm{H}_{\mathrm{a}}$ diterima. 
b. Komitmen Organisasi $\left(\mathrm{X}_{2}\right)$

Variabel komitmen organisasi memiliki tingkat signifikansi t sig. $(0.033)<\alpha(0,05)$. Hal ini menunjukkan bahwa hipotesis yang menyatakan "Komitmen organisasi secara parsial berpengaruh signifikan terhadap kinerja pegawai pada Kantor Kecamatan Parigi Kota" terbukti atau bahwa $\mathrm{H}_{0}$ ditolak dan $\mathrm{H}_{\mathrm{a}}$ diterima.

\section{Pembahasan}

\section{Kepuasan Kerja dan Komitmen Organisasi Berpengaruh Secara Serempak Terhadap Kinerja Pegawai}

Demi mencapai tujuan sebuah organisasi, pegawai memiliki kontribusi yang sangat penting dalam kegiatan operasional organisasi. Oleh karena itu sebuah organisasi harus menerapkan kepuasan kerja dan komitmen organisasi yang baik bagi para pegawainya. Karena diketahui bahwa kepuasan kerja dan komitmen organisasi merupakn faktor penting dalam peningkata kinerja pegawai, karena dengan adanya kepuasan kerja dan komitmen seorang pegawai maka dapat meningkatkan kinerja sebuah organisasi.

Hasil dari uji regresi diperoleh nilai Sig.F sebesar $0,000<0,05$. yang dapat diartikan bahwa variabel kepuasan kerja dan komitmen organisasi secara serempak berpengaruh signifikan terhadap variabel kinerja pegawai pada Kantor Kecamatan Parigi Kota. Hal ini mengambarkan bahwa kantor kecamatan parigi kota sudah menerapkan kepuasan kerja dan komitmen organisasi yang baik bagi para pegawainya, karena dengan diterapkannya kepuasan kerja dan komitmen organisasi bagi para pegawai maka akan mempengaruhi kinerja dari seorang pegawai.

\section{Kepuasan Kerja Berpengaruh Signifikan Terhadap Kinerja Pegawai}

Hasil penelitian dari uji regresi, kepuasan kerja memiliki tingkat signifikan t sig. $(0,003)<(0,05)$. Hal ini menunjukkan bahwa hipotesis yang menyatakan variabel kepuasan kerja secara parsial berpengaruh signifikan terhadap kinerja pegawai pada Kantor Kecamatan Parigi Kota. Dapat di artikan bahwa semakin tinggi tingkat kepuasan yang dirasakan pegawai maka semakin baik pula kinerja pegawai pada kantor kecamatan parigi kota.

Pengaruh kepuasan kerja terhadap kinerja pegawai Kantor Kecamatan Parigi Kota bernilai positif. Hal ini menyatakan bahwa variabel Kepuasan kerja merupakan faktor yang mempengaruhi kinerja pegawai. Jika kepuasan kerja tinggi maka dapat meningkatkan kinerja pegawai. Analisa membuktikan bahwa kepuasan kerja terhadap kinerja pegawai berpengaruh apabila gaji pegawai diterima secara berkala tepat waktu, kondisi lingkungan kerja yang mendukung dan rekan-rekan kerja yang saling membantu satu sama lainya akan menciptakan suatu kinerja yang baik dalam kegiatan bekerja. Kepuasan kerja adalah kondisi yang dirasakan seorang pekerja dalam melakukan pekerjaannya. Hal tersebut menggambarkan senang tidaknya seorang anggota bekerja pada sebuah organisasi.

\section{Komitmen Organisasi Berpengaruh signifikan Terhadap Kinerja Pegawai}

Berdasarkan hasil penelitian uji regresi, komitmen organisasi memiliki tingkat signifikan t sig. $(0,033)<(0,05)$. Hal ini menunjukkan bahwa hipotesis yang menyatakan variabel komitmen organisasi secara parsial berpengaruh signifikan terhadap kinerja pegawai pada Kantor Kecamatan Parigi Kota. Dapat diartikan bahwa jika komitmen organisasi semakin tinggi maka akan baik pula kinerja yang akan dihasilkan oleh pegawai Kontor Kecamatan Parigi Kota.

Pengaruh komitmen organisasi terhadap kinerja pegawai Kantor Kecamatan Parigi Kota bernilai positif. Hal ini menyatakan bahwa variabel komitmen organisasi merupakan faktor yang mempengaruhi kinerja pegawai. Analisa membuktikan bahwa komitmen organisasi terhadap kinerja pegawai berpengaruh apabila, pegawai mempunyai loyalitas dan tanggung jawab seperti rasa memiliki yang sangat besar terhadap sebuah organisasi, maka ketika itu pula mereka dapat memberikan kontribusi dan berperan dalam mencapai tujuan organisasi yang akan mempengaruhi kinerjanya. 
Tolis, M.D.

\section{KESIMPULAN DAN SARAN}

\section{Kesimpulan}

Berdasarkan dari hasil analisis dan pembahasan yang dilakukan , maka dapat disimpulkan sebagai berikut:

1. Kepuasan kerja dan komitmen organisasi berpengaruh secara serempak terhadap kinerja pegawai pada Kantor Kecamatan Parigi Kota.

2. Kepuasan kerja berpengaruh signifikan terhadap kinerja pegawai pada Kantor Kecamatan Parigi Kota.

3. Komitmen organisasi berpengaruh signifikan terhadap kinerja pegawai pada Kantor Kecamatan Parigi Kota.

\section{Saran}

Berdasarkan dari hasil analisa dan kesimpulan yang dilakukan, maka beberapa saran yang dapat diberikan adalah sebagai berikut:

1. Pada variabel kepuasan kerja, disarankan kepada Kantor Kecamatan Parigi Kota agar lebih memperhatikan kepuasan kerja pegawai terutama pada pegawai Non PNS seperti kesesuaian gaji dengan standar yang berlaku. Serta meningkatkan fasilitas kantor agar dapat menunjang aktifitas pekerjaan guna mencapai tujuan bersama.

2. Pada variabel komitmen organisasi disarankan kepada Kantor Kecamatan Parigi Kota agar tetap memberi dukungan dan perhatian kepada seluruh pegawai yang sudah mempunyai komitmen organisasi yang tinggi yang tetap percaya dan setia pada satu organisasi.

3. Pada variabel kinerja pegawai, disarankan kepada Kantor Kecamatan Parigi Kota untuk tetap mempertahankan efisiensi waktu dalam mengerjakan tugas yang diberikan guna mencapai tujuan organisasi.

\section{REFERENSI}

Bayu Aktami, 2007. Kontribusi Kepuasan Kerja Dan Iklim Organisasi Terhadap Komitmen Karyawan, Tesis Mahasiswa Program Magister Psikologi Universitas Gunadarma.

Cut Zurnali. 2010. Knowledge Worker. Kerangka Ruset Manajemen Sumber Daya Manusia Masa Depan. Bandung: Penerbit unpad Press.

Hadari Nawawi. 2006. Evaluasi dan Manajemen Kinerja dilingkunagan Perusahaan dan Industri. Yogyakarta: Universitas Gajah Mada

Noe, Reymond A. et.al. 2006. Human Resource Management. Gaining competitive advantage. Boston: Mc-Graw Hiil.

Prawirosentono, Suryadi, 1999, Manajemen Sumberdaya Manusia: Kebijakan Kinerja Karyawan, Kiat menuju organisasi kompetitif dalam perdagangan bebas dunia, Yoyakarta: BPFE.

Robbins, Stephen. P. 2001. Perilaku Organisasi, edisi 8. Jakarta: Prentice Hall.

Robbins, Stephen. P., 2006. Perilaku Organisasi (alih bahasa Drs. Benjamin Molan)., Edisi Bahasa Indonesia., Klaten: PT. INTAN SEJATI.

Sinambela Lijan Poltak, dkk. 2011. Reformasi Pelayanan Publik. Jakarta: Bumi Aksara.

Sudarmanto. 2009. Kinerja dan Pengembangan Kompetensi SDM. Yogyakarta: Pustaka Pelajar.

Sudarmanto, 2014. Kinerja dan Pengembangan Kompetisi SDM. Yogyakarta: Pustaka Pelajar.

Sugiyono. 2010. Metode penelitan pendidikan pendekatan kuantitatif, kualitatif dan R\&D. Bandung: Alfabeta.

Sugiyono. 2011. Metode Penelitian Kuantitatif Kualitatif dan R\&D. Bandung: Alfabeta.

Sugiyono. 2014. Metode Penelitian Manajemen. Bandung: Penerbit Alfabeta, CV. Cetakan ke-3.

Veithzal Rivai, dan Mulyadi Deddy, 2012. Kepemimpinan dan Perilaku Organisasi. Edisi ketiga. Jakarta: Penerbit PT Raja Grafindo Persada.

Wibowo, 2016, Manajemen Kinerja. Edisi kelima, Jakarta: Rajawali Pers. 